\title{
Exocrine and Endocrine Pancreatic Cancer Pathologic TNM Finding v7
}

National Cancer Institute

\section{Source}

National Cancer Institute. Exocrine and Endocrine Pancreatic Cancer Pathologic TNM

Finding V7. NCI Thesaurus. Code C90285.

A pathologic finding about one or more characteristics of exocrine or endocrine pancreatic cancer, following the rules of the TNM AJCC V7 classification system. 